\title{
Developing the Potential for Change: Challenging Power Through Social Entrepreneurship in the Netherlands
}

\author{
Timo Korstenbroek ${ }^{1} \cdot$ Peer $_{\text {Smets }^{1}}$ (D)
}

Published online: 11 March 2019

(C) The Author(s) 2019

\begin{abstract}
Most research on social entrepreneurship overemphasizes agency by presenting social enterprising as something that originates solely from the intrinsic motivations of individual entrepreneurs. Research that does regard the impact of state power is almost exclusively anchored in and geared toward neoliberal policy contexts. This article examines the dialectics between state power and entrepreneurial counterpower in the institutional context of the Netherlands. Moreover, since social entrepreneurs develop different tactics and strategies for responding to challenges, we use Gaventa's power cube to distinguish forms of power and counterpower, which we then combine with the following inductively derived social entrepreneur typologies: successful hybrids, antagonistic organizers, and autonomous entrepreneurs. This offers insights into the development of theory in relation to the social entrepreneurial potential for change and civic participation.
\end{abstract}

Keywords Social entrepreneurship · Power - Space · Participation · Governance

\section{Introduction}

Although plagued by a conceptual fluidity (Teasdale 2012), most definitions of social entrepreneurship accept its socalled double bottom line: the combination of a primary societal motive with a businesslike entrepreneurial

Peer Smets

p.g.s.m.smets@vu.nl

1 Department of Sociology, Vrije Universiteit, De Boelelaan 1081, 1081 HV Amsterdam, The Netherlands approach (see Germak and Robinson 2014; Zahra et al. 2009). Working from this loose definition, we examine and deconstruct the challenges social enterprises face, challenges that come from the power exerted upon them by the policy environment they are embedded in. The intrinsic motivation and agency of social entrepreneurs are important to understanding the concept of social entrepreneurship. However, most research on social entrepreneurship tends to regard it solely from this unilateral angle, that is, as a phenomenon sprouting solely from the motives and agency of social entrepreneurs (e.g., Gawell 2013; Germak and Robinson 2014; Peredo and McLean 2006; Van Slyke and Newman 2006; Zahra et al. 2009).

Contesting this agentic view, we argue that social enterprises must instead be viewed as being constructed in constant interaction with the political climate in general and its policies and policymakers in particular. We are not the first to make this argument. Especially in the context of the UK, social entrepreneurship has been fervently employed as a neoliberal policy ideal since the late 1990s, with continued promotion by the Big Society in 2010 (Alcock 2010; Mason and Moran 2018; Teasdale 2012). Thus, British policymakers have explicitly promoted the linkage between government policy and social entrepreneurship as a civil society structure meant to "fix Britain's broken society" (Alcock 2010: 380).

Within academia, earlier studies examining the power relationship between government and social enterprise were predominantly anchored in the UK's contemporary neoliberal policy climate. With this article, we aim to contribute to this literature by focusing on the challenges facing social enterprises in the Netherlands, thereby exposing power relationships affecting social enterprises in a context other than the British. Specifically, we ask how social entrepreneurs in the metropolitan area of Amsterdam 
contest the different forms of power exerted upon them by government. As mentioned above, the idea of social enterprise cannot be viewed separately from the influence exerted upon it by government discourses. Nicholls (2010), for instance, has shown how a government can help to discursively structure the legitimacy of social entrepreneurship as a rather nascent concept, while Mason and Moran (2018) have recently traced the purposeful creation of a political myth about social enterprising in the discourse on the British Big Society. Often, such political discourses are lamented for their presumed provocation of a marketization of the third sector (see Dey and Teasdale 2013, 2015; Eikenberry and Kluver 2004).

Yet, however powerful they are, these policy discourses are not indiscriminately adopted into the frames of practitioners. Parkinson and Howorth (2008), for example, argue that social entrepreneurs often use frames of reference different than those promoted in neoliberal entrepreneurial discourses. Moreover, Froggett and Chamberlayne (2004) show how the everyday individual practices of social entrepreneurs differ from those promoted via consumerist policy discourses. And Dey and Teasdale (2013, 2015) demonstrate how policy discourses can be assumed or resisted or in some cases even transcended and negotiated by practitioners into novel variants of the social entrepreneurial discourse. Finally, Kerlin (2006, 2010) presents different models of social enterprise determined by the local culture and socioeconomic environment.

This article focuses on Dutch social enterprises. To obtain insight into the challenges they face, we compare Dutch enterprises with earlier examples originating from the UK. We look beyond the UK's particular neoliberal context, which allows us to sketch the particularities of the contemporary Dutch context before proposing Habermas's system and lifeworld dichotomy and Gaventa's model of power and counterpower as a tool for analyzing the tensions surrounding social entrepreneurship within that context. After outlining our methodology, we discuss the results by presenting three ideal types of Dutch social entrepreneurs, all differing in their responses to various forms of state power. Finally, we briefly summarize and critically discuss these results and propose where and how social entrepreneurs can develop sustainable spaces for profound societal changes.

\section{Expanding the Neoliberal Context: System and Lifeworld in the Netherlands}

Most research on power relations has followed a Foucauldian track or has at least approached power in its ideological and discursive dimension (see Dey and Teasdale 2013, 2015; Mason and Moran 2018; Parkinson and Howorth 2008), which is logical given the (British) neoliberal context in which such research is almost exclusively anchored. To restore social inclusion, UK governments have tried to control the third sector from a distance by championing a discourse of social enterprising as a "normative ideal toward which third sector practitioners are supposed to move" (Alcock 2010; Dey and Teasdale 2015: 4). Yet critics have noted that propagating this discourse offers merely a neoliberal solution to a neoliberal problem (Dey and Teasdale 2015). Critical accounts on power relations within the field of social entrepreneurship have therefore focused mainly on the marketization and commercialization of civil society through this (British) neoliberal discourse (see Dey and Teasdale 2013, 2015).

The manifestation of neoliberalism is composed "of the heterogeneity and contextual specificity associated with market-driven forms of regulatory experimentation." (Brenner et al. 2010: 208). Institutional contexts historically go together with different styles of government involvement, which confront social entrepreneurs with different challenges. In this respect, Hazenberg et al. (2016) distinguish different types of social enterprises, based on ecosystems. For this article, two of those types are relevant: the private-macro type for the British context and the private-micro type for the Dutch. The private-macro type refers to a market-oriented approach with an international focus. Social entrepreneurs in England have to cope with a lack of state subsidies while trying to facilitate a market-based approach. Finance comes from investors and through competitive contracts. The focus of these social entrepreneurs is mainly on the social value of the enterprise, and the incorporation of inclusive labor market policies is not widespread. The private-micro type of social entrepreneurs in the Netherlands is also market-oriented, but it has a local focus. Social entrepreneurs mobilize finance from regional associations and the local government. These entrepreneurs aim at income diversification and the incorporation of a wide range of policies to stimulate integration in the labor market (Hazenberg et al. 2016). Here institutional factors and path dependencies are different, which affects the practices of social enterprises, as will be shown below.

In the Netherlands, government still plays a considerable role in structuring and facilitating the cadres of (civil) society. The recent Dutch policy ideal of a participatory society (in Dutch: participatiesamenleving) envisions relieving pressures on the welfare state and restoring social capital by simultaneously diminishing government involvement and reinvigorating civil society. At first glance, this approach looks similar to the UK's Big Society, but the practical execution of the two differs significantly (Brandsen et al. 2015; Putters 2014; RMO 2013). The Dutch case actually shows more similarities with cases 
found in other continental European countries, most notably Germany, Denmark, and France, where social entrepreneurship is still a young concept that lacks political interest and public understanding (cf., Defourny and Nyssens 2008). That is, while a vague interest in social enterprising in the Netherlands is implied in a recent advisory report (SER 2015), the ongoing uncertainty about the meaning and potentialities of social enterprising this report reveals, combined with the lack of an established string of policies promoting social entrepreneurship, signals the general absence of a Dutch political agenda that aims at controlling civil society via the market.

Instead, emanating from a long tradition of strong government participation, the contemporary Dutch ideal of a participatory society has now created a paradox that characterizes the way in which government exercises power over civil society. Rather than truly relinquishing control, the Dutch government has begun to instrumentalize (Waardenburg and van de Bovenkamp 2014) civil society organizations, which are often regarded as ideal resources in building social capital (Dekker 2002). However, in doing so, the government is forcing its own blueprints onto civil society, paradoxically extending its power rather than diminishing it. Waardenburg and van de Bovenkamp (2014) argue that from a government perspective, this tactic can be effective in reaching its objectives (i.e., building social capital), but they agree with Van Ginkel and Verhaaren (2015) that it also reduces the freedom and ability of civil society actors to invent, build, and shape innovative and autonomous structures that are best fit to provide durable social capital resources.

Hence, in the Dutch institutional context, state power infiltrates the third sector not-at least not only-via ubiquitous entrepreneurial discourses "at a distance" (Dey and Teasdale 2015: 4) but through the often more upfront and overt infiltration of what Trommel (2009) labels a greedy government into the decision-making processes of civil society structures. This implies that the government aims at controlling policies and their implementation. Dutch commenters therefore often employ the Habermasian distinction between lifeworld and system in their work (see Soeterbroek 2015; Van Ginkel and Verhaaren 2015). Within this distinction, the lifeworld constitutes the grassroots realm of citizens and civil society, a realm in which mutual understanding can be reached through pragmatic cultural transmission and social integration. The system, meanwhile, refers to those state institutions whose one-sided administrative rationality all too often "colonizes" the civic lifeworld (Habermas 1984). This has led to an extension of the system's logics and priorities into the lifeworld, thereby impeding the lifeworld from creating grassroots initiatives on its own. We adopt this Habermasian binary as the focal point of departure for our research because this dialectic between lifeworld and system adequately represents the everyday reality facing many Dutch civil society workers confronted with a greedy government.

However, within this Habermasian perspective of system vis-à-vis lifeworld, we do not deny or ignore the existence of more latent forms of power that can affect the nature of civil society in general and social entrepreneurship in particular. We simply wish to propel into the debate a sensitivity to the often more overt forms of state power that steer civil society in other institutional contexts. In addition, this distinction between overt forms of power highlights the presence of different forms of power within the Dutch context. In practice, however, differences in the workings of power are often more subtle than this analytical distinction perhaps suggests and are therefore hard to fully disentangle from each other.

\section{Conceptualizing Power and Counterpower: Forms and Spaces}

Building on knowledge about the practices of citizens' participation and engagement, Gaventa (2006) established a power cube in which different types of power, spaces, and levels were included. We select elements from this power cube that fit our study on social entrepreneurs in the Netherlands. Then, equipped with Habermas's dichotomy between system and lifeworld and the selected elements from his cube, we employ a multifaceted view of power and counterpower that incorporates both the latent and the overt dimensions of the system-lifeworld scheme into our analytical framework. In this section, we first use Gaventa's forms dimension to discern three forms of power. Then, we use his spaces dimension to highlight the agency present in different types of spaces in which these forms of power can be negotiated and contested.

\section{Power: A Tripartition}

In dissecting power, Gaventa (2006) draws from Lukes's (1974) radical view that champions the partitioning of power into three constitutive forms. First, in its most advanced form, power consists of the concealed ideological dispersion of hegemonic discourses that have the potential to normalize the lifeworld (Lukes 1974). Following Gaventa (2006), we label this invisible power. The power of a neoliberal entrepreneurial discourse with a dominant focus on the market, which scholars examining the British context have focused on, resides in this form.

Although the Dutch policy ideal of a participatory society seemingly created a similar discourse of civic selfsufficiency, it has not yet led to a pervasive policy-invoked discourse stressing the commercialization and 
marketization of the third sector. Instead, the ongoing intrusion of the "greedy" Dutch government into civil society has extended a political discourse into the lifeworld that is often unrecognized. That is, with its adherence to liberal-democratic ideals that are often blind to the profound differences existing among actors within the lifeworld, the system has extended rather than mitigated the hegemonic discourses that maintain societal inequalities (Ghorashi 2014; Young 2001, 2002).

Second, the system's influence is often translated into a type of power that is less opaque yet still not transparent. Access to actors in public spaces and their interests is restricted. This form of hidden power is not about the unrecognized dispersion of ideological discourses into the lifeworld but involves the system's ability to set the policy agenda prior to including the lifeworld in the process of decision making (Gaventa 2006). In the UK, this is happening through the creation of an agenda that favors civil society structures adopting entrepreneurial tactics. In the Netherlands, however, it might be described more generically as the government's "pathological tendency to frame initiatives into its own policies and systems" (Soeterbroek 2015: 31), thereby excluding the voice of the lifeworld from its predetermined agenda.

The third and final form of power is the more overt form that most vividly evokes the Habermasian idea of the colonization of the lifeworld that we argue is integral to comprehensively understanding the challenges social entrepreneurs encounter within the Dutch context. This overt form of power is what Gaventa (2006) calls visible power, which essentially describes one actor's (the system's) ability to observably force another actor (the lifeworld) to do something (see Lukes 1974). Examples from the system-lifeworld binary include government regulations that require financial support for civil society projects or stringent judicial legislation that impedes the initiation of innovative projects.

\section{Counterpower: Discovering Spaces for Change}

State power is never absolute; counterpower readily exists among social practitioners formulating their own frameworks, as Dey and Teasdale $(2013,2015)$ and Parkinson and Howorth (2008) have illustrated. While these scholars have provided valuable and usable insights into different types of resistance and negotiation, the neoliberal context their work is embedded in ultimately creates a focus different than ours. Contrary to the UK, where the market dominates in the neoliberal discourse, the Dutch case shows a larger role for the public sector. That is, for the scholars analyzing the British context, counterpower entails a way of challenging the marketization of civil society by actually contesting a neoliberal policy discourse that overly promotes social entrepreneurship. But in the Dutch context, a greedy government usurps the lifeworld's autonomy, making counterpower manifest itself as a strategic reaction against that greediness. Hence, we advocate that social entrepreneurship in the Dutch context should not be viewed as the dreaded marketization of civil society; instead, it should be seen from a more positive perspective-ironically, one often found in previously refuted agentic scholarly works (e.g., Van Slyke and Newman 2006; Zahra et al. 2009) as a potential way through which civil society actors can reach higher levels of organizational autonomy and societal innovation.

Our interest in counterpower therefore consists of illuminating how social entrepreneurs negotiate or resist the different forms of power the system exercises over the lifeworld in the Netherlands. Thus, in line with Gaventa's (2006) second dimension, we ask where we can find suitable spaces for change. Again, Gaventa distinguishes three types of spaces. The first type, closed spaces, is of less importance for our research because it presumes a type of space that is entirely closed off from any form of citizen participation (Gaventa 2006). Since social entrepreneurship is in fact a form of civic engagement, we cannot expect to encounter descriptions of entirely closed spaces when analyzing our data. This type does, however, point us to the fact that in some cases, the freedom to affect, build, and shape policies can be heavily restricted by the regulatory frameworks in place.

Yet, even in extreme cases of severe restrictions, there is always a space, however small, for social entrepreneurs to dive into, at least in the Dutch democratic context. Such spaces are invited spaces, where the system asks the social entrepreneur to collaborate within a predetermined framework (Gaventa 2006). Social entrepreneurs in such spaces are operating inside the system, acting as either happy infiltrators - trying to steer the system from within-or $\mathrm{co}$ producers-working together with and abiding by the system's terms (Soeterbroek 2015).

This ideal of invited spaces mirrors the (neo-)corporatist model of (new public) governance, in which governments strive toward inclusion and invite civil society to construct society collectively (Osborne 2006; Pierre 1999). Corporatist governance has long been employed in small European democracies such as the Netherlands (Pierre 1999). However, Gaventa's third space-the created space-is gaining importance and effectiveness. Within created spaces, actors actively denounce the structures proposed by the system and create wholly new ones outside the system's boundaries (Gaventa 2006). Although such spaces seem appropriate for the contemporary Dutch policy environment, the question remains, as argued above, to what extent is the greedy Dutch government actually willing to relinquish its forms of power over the lifeworld 
by freely allowing a societal proliferation of created spaces?

As we proceed, these analytical tripartitions will guide and structure the following questions on state power and entrepreneurial counterpower: What forms of state power do social entrepreneurs encounter? What meaning do social entrepreneurs give to those forms, and what (counter)actions do they take? Do they antagonistically create spaces outside the system, or do they work within the frameworks of invited spaces? And finally, through what spaces do social entrepreneurs find durable solutions to challenge the system's power and to reinvigorate the lifeworld's potential?

\section{Methods}

Though the idea of visible power might seduce one into thinking of power in a realist sense, as something objectively out there, the concepts of hidden and invisible power reveal the tacit and constructed nature of power. Moreover, the notions of resistance and counterpower emphasize the construction of narratives against all three types of power. We therefore insist that to understand the dialectics of power and counterpower, this tension cannot be analyzed directly as it appears. Rather, to grasp its reality, one must aim at unraveling the way it is subjectively constructed by analyzing meanings. Thus, the study becomes one on subjective ideals rather than objective realities (Yanow 2006). The question for this article focuses on counterpower, asking how social entrepreneurs apply meaning to different forms of power and in what different ways they construct counternarratives.

We conducted 21 semi-structured, in-depth interviews with social entrepreneurs in metropolitan Amsterdam. Respondents were initially chosen by approaching entrepreneurs fitting the loose definition provided in introduction. Additional entrepreneurs were located via snowball sampling. All interviewees held critical positions within their organizations and therefore were able to speak on behalf of their enterprises.

The interviews were conducted in two waves in 2015 and 2016 by postgraduate students of sociology at Vrije Universiteit Amsterdam. In groups of 2-3, students interviewed individual social entrepreneurs and transcribed the interviews. To guarantee congruence between the interview content and the research results, an interview guide was constructed collectively under supervision of the second author. One of the main themes within this guide was the tension between government power and social entrepreneurs' innovative freedom to create counterhegemonic spaces, this article's central issue. To ensure the anonymity of the interviewed entrepreneurs, we used pseudonyms for both personal and company names throughout this article.

Results were analyzed, and a coding scheme was constructed using qualitative data analysis software (ATLAS.ti). We used a more deductive theory-driven approach during the initial phase of coding. That is, the forms and spaces of Gaventa's power cube were used as sensitizing concepts (Bowen 2006) that provided a structural framework for the data. Thus, whenever an example of a created space was discovered in the data, it was coded as such. In addition, a second track of coding was used to provide body to these sensitizing concepts as well as to corroborate their existence. These codes were more open and inductive, arising from the data itself, which allowed us to both distinguish and draw lines between the social entrepreneurs' differing tactics, motivations, and struggles within and between Gaventa's dimensions.

Finally, reviewing the clusters of codes that emerged from this coding scheme led to the construction of the following typologies (see Spencer et al. 2014) of social entrepreneurs: successful hybrids, antagonistic organizers, and autonomous entrepreneurs. While containing the basic characteristics of social entrepreneurship, these three typologies were distinct and clearly delineated epitomes of social entrepreneurial positions vis-à-vis government power. However, the qualitative interpretative nature of our study does not allow for an unquestioning generalization of these results or their immediate application into other settings.

\section{Social Entrepreneurs in Metropolitan Amsterdam}

While most social entrepreneurs certainly lean more toward one type or another, the different roles always overlap to some extent. Figure 1 highlights this conjunctional nature by presenting the three types of social entrepreneurs in a Venn diagram, emphasizing both their similarities and differences.

One exemplary entrepreneur, Laura, works for an enterprise called Waterside, a cooperative dedicated to stimulating local civic participation at the neighborhood level. This social enterprise offers office space in its building to entrepreneurial citizens who want to start their own social enterprise providing either activities or products. Thus, Laura's enterprise has a transparent primary societal mission-advocating civic participation and engagement-while it also upholds clear financial objectives focused on self-maintenance rather than profit maximization. As Laura explains:

You always have that economic stimulus; you have to renew; you have to find ways. You have to act in the service of the neighborhood, but you also have to 


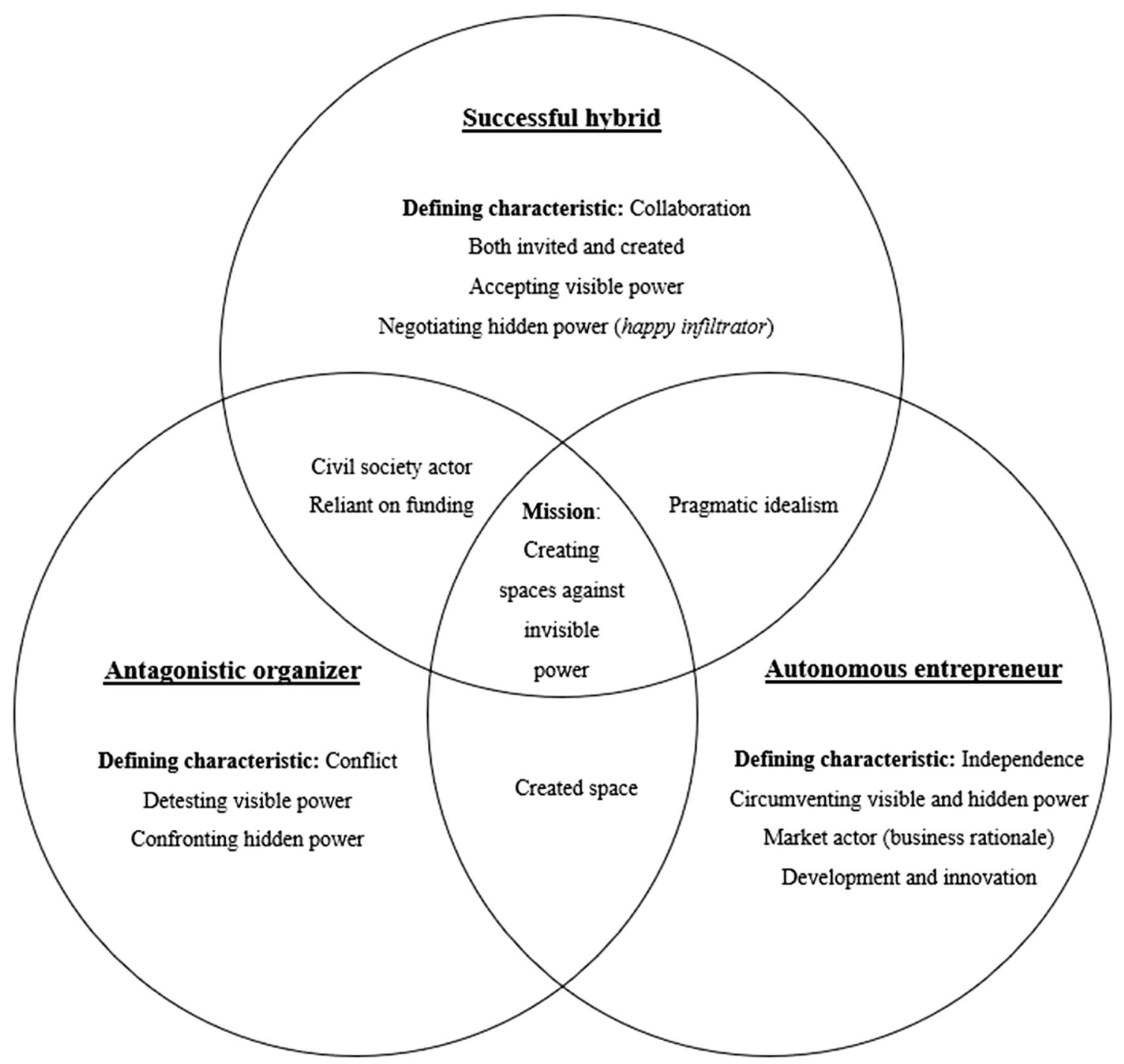

Fig. 1 Differences and similarities of three types of social entrepreneurs

maintain yourself [financially], so that creates a constant challenge.

Here we see that Laura has to juggle the societal, economic, and financial elements of her social enterprise. Using Waterside as a primary example that encompasses all three entrepreneurial types, we now focus on the different tactics of successful hybrids, antagonistic organizers, and antagonistic entrepreneurs.

\section{Successful Hybrids}

Successful hybrids are entrepreneurs who succeed in balancing between power and counterpower in order to reach their objectives. Thus, the term hybridity is used to denote the ambivalent nature of employing invited spaces and created spaces simultaneously. Thus, while hybrid tactics are used to complement government policy, novel participatory spaces are simultaneously created outside policy frameworks. For Laura, creating new spaces means empowering citizens at the grassroots level and encouraging them "to do it themselves." Yet, she quickly adds that such civic emancipation is to be reached "eventually, actually, in collaboration with the local city district." This idea of being an intermediary between system and lifeworld (see Van Hulst et al. 2012) is the defining characteristic of a successful hybrid style of social enterprising.

The hybrid approach contains an ideally negotiated balance between government power and civic counterpower. What this entails in practice is that both parties act mutually beneficially. To create a symbiotic work environment that allows for the successful creation of novel spaces within the government's policy interest, both parties are willing to relinquish control when necessary. The hybrid approach also requires social entrepreneurs' 
tolerance of two interconnected visible power components: funding requirements and judicial regulations. In Waterside's case, local government funding was needed to start the social enterprise. Thus, to secure its financial lifeline, the organization was forced to meet local regulatory requirements such as obtaining specific catering industry certificates. As Laura explained, "The city district tells you that there is a certain way that this is supposed to be done, and if you do not have that [the certificates], you will not get any money." The first key to successful social entrepreneurship is to accept such expressions of visible power as a reality of doing business:

Eventually one always runs up against the government. So, what we understood really quickly although this was quite a hassle at first - is that you have to embrace government, extensively work with

it. That is why we work together with governments a lot. (Sander, Y side)

At the same time, a second prerequisite for successful hybrid enterprising stresses the role of governments in acknowledging and relinquishing their often restraining influence through visible power on the (mainly) extra-institutional objectives of social entrepreneurs. Thus, Laura emphasizes:

Government can have a strong facilitating role. That is, they can become a bridging party between different stakeholders. That is what a government can do best, together with helping and supporting you with judicial and regulatory issues.

However, for government to facilitate social entrepreneurs' unorthodox tactics, it must take a lenient approach, which can greatly ease some of the (financial) challenges social entrepreneurs encounter. Noor, from a neighborhood center, recounts a conversation she had with city district officials over what she perceived as too stringent of regulations:

[I told them] "Sorry, but if you want me to report exactly who comes here, I have to switch to a really expensive accounting software package, which will cost around 6000 euros." Then the city district said, "We scratch that [requirement]". And they just scratched it!

Contesting the hidden agenda-setting power from a successful hybrid perspective entails not a radical denial and reformulation of the government agenda but a modification of the agenda from within, much like Soeterbroek's (2015) happy infiltrator concept. However, the extent to which this modification process is imbued in social entrepreneurs' tactics varies from case to case. Waterside, for example, ran into an issue with the local government's agenda, which postulated that there could be no overlap in objectives between the local initiatives in the neighborhood. They inventively resolved this issue not by opposing the hegemonic agenda but by creating lines of dialogue and cooperation with potentially competing initiatives at the local level.

Successful hybrids thus work in both invited and created spaces. Sander (Y side), for example, tries to create new forms of civic participation by empowering citizens at the grassroots level before aligning their projects with government policy interests. The Wastelab enterprise positions itself further away from the lifeworld and thus conforms more neatly to local agendas. Aiming to promote a circular economy, this enterprise enters the lifeworld with predetermined objectives constructed in consultation with local officials in order to find usable tactics in recycling garbage. Thus, for The Wastelab, there are limited opportunities to truly open up created spaces. Instead, its practices can be viewed as the practical fulfillment of a government's predetermined invited space. Notwithstanding these gradual differences, the shared negotiated position between government and civil society means that all of the above examples can be called successful hybrid enterprises.

Finally, as Anton (Refugee Aid) suggests, successful hybrid tactics always seem to be idealistic and anti-dogmatic. That is, they challenge the legitimizing invisible power diffused through society by seeking to reinforce novel ties between citizens. Voicing this idealistic desire to break with invisible power structures, Anton states:

Amsterdam is still mostly a dominant white society.

[...] We are so dominant in our "Dutchness". I

believe that we could become more open, especially

richer, if we were to allow more people into our

discourse on a much broader scale and allow them to

leave their mark on the society that we are.

Successful hybrid enterprising thus evokes Ghorashi's (2014) inclusive ideal of forging routed connections and Young's $(1996,2002)$ vision of a communicative democracy, both of which attempt to break with the normative invisible discourses-often upheld by government policies-that prolong social inequalities in the everyday practices of the lifeworld.

In sum, a successful hybrid is characterized by collaboration with different parties, which can take place in invited and created spaces. It deals with the different types of power by accepting visible power and negotiating hidden power. The focus of civil society actors is often local and is reliant on funding. The mission of the hybrid model is pragmatic idealism and creating spaces against invisible power. In other words, the successful hybrid's idealism tends to break with the invisible walls of hegemonic symbolic power structures. 


\section{Antagonistic Organizers}

The second type of social entrepreneur differs in its reaction to visible and hidden power constructs. Antagonistic organizers struggle with the notion of collaboration and mutual concessions. They radically aim to work outside the institutional frameworks. Yet their institutional makeup as local and relatively small civil society actors means that they regularly encounter and are also (financially) dependent on the government's terms. However, instead of working with the system's invited spaces, they work to build entirely new created spaces outside any external influence-while simultaneously being unable to gain full autonomy from state support. Thus, they resemble Soeterbroek's (2015) activist type of civil society actor, whose defining characteristic is one of conflict.

Just as we cannot ascribe the success of the hybrid type solely to the government or to the entrepreneur, we similarly cannot state that the antagonistic organizer's failure to collaborate successfully is due to only one party or the other. Moreover, such a statement would be beside the point, for not only does the qualitative interpretative approach in this research prevent us from making any statements on causality, doing so would undermine our acknowledgment of the complex tensions between power and counterpower. Therefore, we assume antagonism among social entrepreneurs arises from both greedy governments (Trommel 2009) and one-sided agency-driven views among social entrepreneurs themselves.

Though Laura, as previously shown, acknowledged the (financial) need to allow visible power that does not mean that Waterside adopted a wholly hybrid stance. As she implied throughout the interview, the government requirements were often seen as serious limitations to the enterprise's objectives:

Getting the required permit took ridiculously long [...]. This made us fall behind schedule [...]. That, for me, shows the inflexibility of government and that everyday practice is simply different [than their world].

To overcome such challenges, the organization pursues financial autonomy from local government rather than working with it. Laura said: "Receiving a subsidy means that some other party has some say over you, which subsequently means that you lose autonomy."

Although Waterside still has to deal with local regulatory requirements, such as requesting permits, seeking financial autonomy is one tactic that has proven to be relatively successful for these social entrepreneurs (see the next section). However, for many entrepreneurs functioning within civil society-that is, those without a clear product to sell on the market-this seems a utopian endeavor because their revenue still relies on government funding. Whenever the visible power stipulations (i.e., funding and regulatory requirements) are perceived as being too suffocating for the entrepreneur, an antagonistic stance, rather than a hybrid one, will be assumed. While such antagonistic tactics can prove successful in reaching an enterprise's objectives, antagonistic organizers' inherent denunciation of any form of government power puts them in a paralyzing state of perpetual conflict and struggle with the government's logic. In describing his business model, one entrepreneur illuminatingly captures the rigidity on both sides that undergirds this antagonism. He emphasizes the government's inability to grasp the unquantifiable grassroots nature of many social enterprises as well as the entrepreneur's unwillingness to adapt to the government's logic.

Our business model is based on allowing government to capitalize on the added societal value we create [...]. And what you see is that the government market model measures almost everything: the height of the grass, the number of street lanterns, safety. But added societal value is an unmeasurable substance for them. They cannot do anything with it. [...] [However] we try to capitalize on this added value via government subsidies, which [...] would mean we got a solid business model. Yet if the government does not capitalize on it $[\ldots]$, we stay a social organization with a poor business model, but with societal impact and satisfied users. (Paul, Doing Things Differently)

In terms of hidden power, an antagonist entrepreneurial style does not attempt to remodel the societal agenda from within but instead works against the very grain of the agenda(s). Laura explains one problem regarding the city district's agenda:

They categorize everything; you cannot do that in such a formal way as a citizen. But the city district only makes a distinction between people who participate and people who do not, while there is an entire world in-between.

This reverberates with the intrusion of government blueprint thinking into civil society (Van Ginkel and Verhaaren 2015). Moreover, rather than one single agenda, many entrepreneurs speak of multiple government agendas. One even goes so far as to describe local government as a manyheaded monster, while another notes the following:

In the field, there is an ongoing bickering between professionals over who gets to do what job. For me, that meant $[\ldots]$ that I was only trying to align these different professionals. Everyone simply had their 
own agenda, while my agenda is merely to do what the citizen wants. (Robert, Neighborhood Enterprise)

Different government agendas thus denote different objectives, which can vary from the often bottom-up objectives of social entrepreneurs. Hence, as Frank, who runs a communal garden, notices, creating a new space through a complete "take-over of the public space is difficult." Although government might initially support this under the flag of civic participation, "when push comes to shove, they become hesitant." Because of their double agendas, questions like these arise: "What will this mean for the [garden's] neighbors? And what is it they [the social enterprise] want exactly?" However, Frank does not let this affect his own agenda: "This conflicts with their objectives a little, but not with my own." This is where antagonism separates itself from hybridity: It moves more sharply away from a place with(in) the dominant agenda to a space confronting or rejecting it, sometimes even offering democratic alternative modes of agenda setting:

They [the government] are entangled in a battle, but they do not provide the right example. We are looking for other democratic models. [...] Budget monitoring, for example, is a far-reaching instrument that lets citizens and government monitor government spending in conjunction. [...] Listen to the people themselves for a change. What do they want? (John, neighborhood restaurant)

Nevertheless, both hybrid and antagonist styles often exist in close proximity to each other and are therefore not exclusive concepts. A social entrepreneur may view certain nuanced visible government stipulations or hidden agendas as acceptable - thus informing a hybrid tactic-while seeing slightly less considerate power expressions as intolerable, thereby sparking antagonism. Moreover, what might seem antagonistic at first is often simply the expression of a deep-rooted wish for more effective collaboration between system and lifeworld. Zahra et al. (2009), for example, call for a highly hybrid model that includes both citizens and government. Therefore, the distinction between the two types should not be seen as rigid, but rather as indicating the cardinal challenge for the future development of social entrepreneurship: how to transform oppressive antagonism into symbiotic hybridity.

In sum, the antagonistic organizer's mission is to create spaces against the influence of the system's power. By denying the visible, hidden, and invisible cadres set by government, this social entrepreneur works in constant conflict with the system. The created spaces thus take the shape of disruptive new forms of participation that challenge the predetermined stipulations.

\section{Autonomous Entrepreneurs}

The final type, the autonomous entrepreneur, differs more distinctly from the previous two though several important commonalities do exist. It shares with antagonistic organizers a predilection for disrupting the government status quo and creating intrinsically novel spaces. But it also reflects the hybrid model's pragmatic or realistic approach that can concede and move beyond some of its idealistic core in order to ultimately achieve its overarching moral objectives. While a hybrid tactic is to accommodate the government's system, an autonomous tactic is to mold itself to suit the commercial market.

Within our sample, Vincent (The Enterprise) most clearly embodies this type. His enterprise's mission is to illuminate and eradicate the added natural and social costs of products. He sells his methods and expertise to commercial parties in order to help visualize and ultimately lower these parties' external costs and create a more sustainable global economy. Therefore, Vincent is forced to balance and combine a realistic commercial approach with an idealistic social one. Maintaining the discipline to find this balance, according to Vincent, is one of the main feats of his style of enterprising:

You become disciplined [...]; you become efficient

[...]. To my mind, it is mainly about your mindset

[...] that you do not only have ideals but also a cer-

tain realism to reshape those ideals according to the

hard world that simply exists out there.

This market-oriented approach allows autonomous entrepreneurship to habitually circumvent government influence, making independence its defining characteristic. As Vincent stresses, his enterprise is "totally independent from government subsidies," and although this means he often "balances on a tightrope without a safety net," he claims this independence constitutes his enterprise's strength:

We view it as our strength that in recent years, we have been able to work with companies directly. It makes us very critical in evaluating how good our method is, instead of just receiving a subsidy [...] and not being judged on how well we do our work.

Hence, as autonomous enterprises like Vincent's move toward the market and their financial goals no longer depend on the government subsidies, the visible forces of government lose their power. Similarly, Laura's Waterside also strives to gain its own revenue through the market. Waterside does so by renting out space to aspiring social entrepreneurs. Laura emphasizes that this strategy aims to prevent any form of over-reliance on state services, saying that "subsidies are nice and all, but they make you 
dependent," before adding that "they also hamper your own innovative development." The belief that commercial incentives "challenge you to keep developing" resonates in the views of other social entrepreneurs who, to some extent, rely on the economic market for their revenue. Noor's neighborhood center, for instance, runs largely on revenues obtained through its customers. Therefore, she constantly works to create new projects that further both the center's societal agenda to increase civic participation in the neighborhood as well as the finances needed to execute that agenda. Describing this continuous process, Noor states:

You simply have to work really hard for this [...]. We have to deliver quality, because people need to get what we promise them. [...] So, in addition to renting out rooms, we ran a bar, [...] and after 2 years of running that, I got a kitchen, because then we got someone from this neighborhood who gave workshops and did catering, and he opened up his own restaurant, which I took over [...]. So, there, we offer workshops on a daily basis [...], and you can now order catering from 12 different countries made by local residents. And we also offer neighborhood meals 6 nights a week.

This emphasis on development and innovation reveals the main virtue of autonomous entrepreneurial tactics. They make it possible for entrepreneurs to not only avoid the influence of visible power but also dispatch hidden power and give shape to their own agendas, since economic independence from government makes room for the creation of an agenda that can be as far-reaching as possibleas long as there is a commercial interest for it. With regard to this, Vincent emphasizes:

Most important is that we have an innovation agenda [...]. That is, that you eventually find innovative ways that not only reduce societal costs but are also profitable financially speaking.

Therefore, moving toward the market is a potential way to foster successful social entrepreneurship. This does not mean that the framework of autonomous entrepreneurship is an off-the-rack concept that can ensure success; it merely posits a way to evade the intrusion of potentially paralyzing government power into the practice of social enterprising. However, critical eyes might rightfully object that this type of entrepreneur is shaped by the policy-induced (entrepreneurial) discourses emphasizing marketization and civic self-reliance that are often alluded to in the British context (e.g., Dey and Teasdale 2013, 2015; Parkinson and Howorth 2008).

Finally, an autonomous entrepreneur's success in gaining independence from state power depends on an enterprise's ability to sell a clear product on the market. Some social entrepreneurs, however, offer services that provide what Paul (Doing Things Differently) described as "added societal value," a concept so nebulous that it can hardly be commodified as a commercial product. For those entrepreneurs, the move toward a more market-oriented autonomous entrepreneurial style of enterprising is difficult, making them reliant on government as the only remaining interested party to financially support their "product."

In sum, the autonomous entrepreneur is characterized by working independently on development and innovation within the social enterprise. Such entrepreneurs, who have a business rationale, distance themselves from visible power restrictions posed by financial dependency and judicial accountability. Similarly, they circumvent the government's hidden power to frame initiatives according to their own policy agendas. Because they rely solely on the market's demand for their product, they aim to create novel spaces to open up new forms of engagement and participation outside hegemonic structures.

\section{Conclusions}

Kerlin showed that social enterprises are determined by the local culture and socioeconomic environment, which requires a contextual approach of neoliberalism. Context also influences the type of enterprise developed, and the institutional context and path dependency affect an enterprise's operation. This study focused on market-oriented social enterprises with either an international or local focus, called the English private-macro type and the Dutch private-micro type, respectively (Hazenberg et al. 2016). We focused first on the literature about cases in the UK and compared it with results derived from a qualitative study in the Netherlands. This offered insight into the ways social entrepreneurs cope with business challenges as they try to balance between financial and social aims.

Furthermore, we separated the specifics of the Dutch context from the British and then introduced Habermas's system-lifeworld binary to illuminate the intrusion of more upfront forms of power by a "greedy government" within the Netherlands. Additionally, we used Gaventa's multifaceted approach to power and counterpower to further elaborate on this system-lifeworld scheme by introducing the latent and overt forms in which the system's power manifests itself. Subsequently, using Gaventa's dimension of spaces for counterpower, we then traced how power is contested within the lifeworld.

In doing so, we found three types of social entrepreneurs, distinguished by their reactions to government power. First, the successful hybrid is characterized by 
maintaining a negotiated position between the government's visible and hidden power stipulations, while simultaneously trying to challenge invisible power structures. Second, the antagonistic organizer refutes all three types of power altogether and consequently finds themselves in constant conflict with government structures. Third, the autonomous entrepreneur aims at commodifying a product on the economic market, thereby circumventing any power restrictions the system poses and securing their own independence. Of these three types, we argue that the antagonistic organizational style has the least potential for developing the emancipatory capabilities of social entrepreneurship because it is epitomized by a paralyzing stalemate between two adversarial parties: the government and the social entrepreneur. While antagonistic entrepreneurs may sometimes reach their objectives, their tactics provoke a consistent lack of government support that ultimately hampers the development of their enterprises. The crucial challenge to the development of an enterprise's full potential therefore becomes converting antagonism into either a hybrid or an autonomous style of enterprising.

Our analysis contributes to the theorization of power struggles within the field of social entrepreneurship by showing the different types of government power and tactics that Dutch social entrepreneurs assume to counter them. An entrepreneur's choice of tactics seems contingent on the ability to find a commercial market in which to sell a tangible product. Often, successful entrepreneurs employ some combination of hybrid and autonomous tactics by using their innovative drive to develop a commercial strand that secures independence, while simultaneously conceding that collaboration with government warrants existential security and societal approval. However, our findings should not be taken indiscriminately. For this specific case and context, a follow-up study is recommended in order to corroborate the social entrepreneur typologies found and to potentially discover additional ones. Moreover, research on power and social entrepreneurship in other local and national contexts is required to further map out the differences and commonalities between various contexts.

Acknowledgements We are grateful to all the sociology master's students at the Vrije Universiteit Amsterdam who conducted interviews. We also thank the participating social entrepreneurs for receiving the students. Without the involvement of both groups, this paper could not have been written.

\section{Compliance with ethical standards}

Conflict of interest Concerning this article there is no conflict of interest, financially or non-financially, directly or indirectly related to the work.

Open Access This article is distributed under the terms of the Creative Commons Attribution 4.0 International License (http:// creativecommons.org/licenses/by/4.0/), which permits unrestricted use, distribution, and reproduction in any medium, provided you give appropriate credit to the original author(s) and the source, provide a link to the Creative Commons license, and indicate if changes were made.

\section{References}

Alcock, P. (2010). Building the Big Society: A new policy environment for the third sector in England. Voluntary Sector Review, 1(3), 379-389.

Bowen, G. A. (2006). Grounded theory and sensitizing concepts. International Journal of Qualitative Methods, 5(3), 12-23.

Brandsen, T., Trommel, W., \& Verschuere, B. (2015). The state and the reconstruction of civil society. International Review of Administrative Sciences, 82(4), 676-693.

Brenner, N., Peck, J., \& Theodore, N. (2010). Variegated neoliberalization: Geographies, modalities, pathways. Global Networks, $10(2), 182-222$.

Defourny, J., \& Nyssens, M. (2008). Social enterprise in Europe: Recent trends and developments. Social Enterprise Journal, 4(3), 202-228.

Dekker, P. (2002). De oplossing van de civil society: Over vrijwillige associaties in tijden van vervagende grenzen. The Hague: SCP.

Dey, P., \& Teasdale, P. (2015). The tactical mimicry of social enterprise strategies: Acting 'as if' in the everyday life of third sector organizations. Organization, 23(4), 1-20.

Dey, P., \& Teasdale, S. (2013). Social enterprise and dis/identification. Administrative Theory \& Praxis, 35(2), 248-270.

Eikenberry, A. M., \& Kluver, J. D. (2004). The marketization of the nonprofit sector: Civil society at risk? Public Administration Review, 64(2), 132-140.

Froggett, L., \& Chamberlayne, P. (2004). Narratives of social enterprise: From biography to practice and policy critique. Qualitative Social Work, 3(1), 61-77.

Gaventa, J. (2006). Finding the spaces for change: A power analysis. IDS Bulletin, 37(6), 23-33.

Gawell, M. (2013). Social entrepreneurship: Action grounded in needs, opportunities and/or perceived necessities? VOLUNTAS: International Journal of Voluntary and Nonprofit Organizations, 24, 1071-1090.

Germak, A. J., \& Robinson, J. A. (2014). Exploring the motivation of nascent social entrepreneurs. Journal of Social Entrepreneurship, 5(1), 5-21.

Ghorashi, H. (2014). Routed connections in late modern times. In A. M. Vieten (Ed.), Revisiting iris marion young on normalisation, inclusion and democracy (pp. 49-66). London: Palgrave Macmillan.

Habermas, J. (1984). The theory of communicative action: Vol 2: Lifeworld and system: A critique of functionalist reason. Boston: Beacon Press.

Hazenberg, R., Bajwa-Patel, M., Mazzei, M., Roy, M., \& Baglioni, S. (2016). The role of institutional and stakeholder networks in shaping social enterprise ecosystems in Europe. Social Enterprise Journal, 12(3), 302-321.

Kerlin, J. (2006). Social enterprise in the United States and Europe: Understanding and learning from the differences. VOLUNTAS: International Journal of Voluntary and Nonprofit Organizations, 17, 247-263.

Kerlin, J. (2010). A comparative analysis of global emergence of social enterprises. VOLUNTAS: International Journal of Voluntary and Nonprofit Organizations, 21, 162-179.

Lukes, S. (1974). Power: A radical view. London: Macmillan. 
Mason, C., \& Moran, M. (2018). The tale of the veil: Unweaving Big Society and the social enterprise myth. In P. Dey \& C. Steyaert (Eds.), Social entrepreneurship: An affirmative critique (pp. 75-99). Cheltenham: Edward Elgar.

Nicholls, A. (2010). The legitimacy of social entrepreneurship: Reflexive isomorphism in a preparadigmatic field. Entrepreneurship Theory and Practice, 34(4), 611-633.

Osborne, S. P. (2006). The new public governance. Public Management Review, 8(3), 377-387.

Parkinson, C., \& Howorth, C. (2008). The language of social entrepreneurs. Entrepreneurship and Regional Development, 20(3), 285-309.

Peredo, A. M., \& McLean, M. (2006). Social entrepreneurship: A critical review of the concept. Journal of World Business, 41(1), $56-65$.

Pierre, J. (1999). Models of urban governance: The institutional dimension of urban politics. Urban Affairs Review, 34(3), 372-396.

Putters, K. (2014). Rijk geschakeerd: Op weg naar de participatiesamenleving. The Hague: SCP.

RMO. (2013). Terugtreden is vooruitzien: Maatschappelijke veerkracht in het publieke domein. The Hague: RMO.

SER. (2015). Sociale ondernemingen: Een verkennend advies. Advies 15/03. The Hague: SER.

Soeterbroek, F. (2015). Stadsmakers als happy infiltrators in de systeemwereld. In S. Franke, J. Niemans, \& F. Soeterbroek (Eds.), Het nieuwe stadmaken: Van gedreven pionieren naar gelijk speelveld (pp. 31-42). Trancity ${ }^{\mathrm{x}}$ valiz i.s.m. Jaar van de Ruimte en Platform 31, Amersfoort.

Spencer, L., Ritchie, J., Ormston, R., O’Connor, W., \& Barnard, M. (2014). Analysis: Principles and processes. In J. Ritchie, J. Lewis, C. McNaughton Nicholls, \& R. Ormston (Eds.), Qualitative research practice: A guide for social science students and researchers (pp. 269-294). London: Sage.

Teasdale, S. (2012). What's in a name? Making sense of social enterprise discourses. Public Policy and Administration, 27(2), 99-119.
Trommel, W. A. (2009). Gulzig bestuur. Boom/Lemma, The Hague: Inaugural Lecture.

van Ginkel, J., \& Verhaaren, F. (2015). Werken aan de wakkere stad: Langzaam leiderschap naar gemeenschapskracht. Deventer: Vakmedianet.

van Hulst, M., de Graaf, L., \& van den Brink, G. (2012). The work of exemplary practitioners in neighborhood governance. Critical Policy Studies, 6(4), 434-451.

van Slyke, D. M., \& Newman, H. K. (2006). Venture philanthropy \& social entrepreneurship in community redevelopment. Nonprofit Management \& Leadership, 16(3), 345-368.

Waardenburg, M., \& van de Bovenkamp, H. (2014). Civil society organizations as a government steering mechanism: A comparison between sport associations and patient organizations in the Netherlands. In T. Brandsen, W. Trommel, \& B. Verschuere (Eds.), Manufacturing civil society: Principles, practices and effects (pp. 70-95). Basingstoke: Palgrave Macmillan.

Yanow, D. (2006). Neither rigorous nor objective? Interrogating criteria for knowledge claims in interpretive science. In D. Yanow \& P. Schwartz-Shea (Eds.), Interpretation and method: Empirical research methods and the interpretive turn (pp. 67-88). Armonk, NY: M.E.Sharpe.

Young, I. M. (1996). Communication and the other: Beyond deliberative democracy. In S. Benhabib (Ed.), Democracy and difference: Contesting the boundaries of the political (pp. 120-135). Princeton: Princeton University Press.

Young, I. M. (2001). Activist challenges to deliberative democracy. Political Theory, 29(5), 670-690.

Young, I. M. (2002). Inclusion and democracy. Oxford: Oxford University Press.

Zahra, S. A., Gedajlovic, E., Neubaum, D. O., \& Shulman, J. M. (2009). A typology of social entrepreneurs: Motives, search processes and ethical challenges. Journal of Business Venturing, 24(5), 519-532.

Publisher's Note Springer Nature remains neutral with regard to jurisdictional claims in published maps and institutional affiliations. 